\title{
Twins must be killed
}

\author{
Dirk Bernardus Urus
}

Among the Ayamaru people who inhabit the hinterlands in the Bird's Head, there was a belief that when a woman gave birth to twins, one of the babies must be put to death because it was considered to be the Devil's child. The one who killed the child was the mother herself. However, this belief increasingly eroded with the coming of religious teachers and civil servants to the interior.

The establishment of hospitals made this practice gradually disappear. If we (religious teachers, civil servants, or paramedics) came across a pregnant woman who was going to give birth, she was brought the hospital. If it turned out that she gave birth to twins, one of them was kept at the hospital and could be adopted by interested people.

Another adat practice was found among the Arfak tribe, who also dwell in the Bird's Head area. A woman who was about to give birth was isolated from her community; a separate house was built for her. She gave birth alone and raised the baby on her own without anyone else's help for about one month. Of course, her food and drinks were prepared by other women. However, they only placed the provisions in a certain place, where the new mother would come to pick them up.

But over time, they were able to change due to the existence of government regulations as well as health services provided by doctors and paramedics. Dutch doctors began coming into the forests on patrols to visit the residents of the villages. The people were happy to receive them and their visits had a good influence on the community. If any of the Arfak were hiding in the forests, when the doctors or paramedics came by, they would be sure to come out of hiding to see them. They were glad when the doctors or paramedics came. But if those who came were the police, they did not like it, because the police might be violent toward 
them. Even if nothing had happened, just hearing the name police would frighten them. Thus, in they could treat people who were sick.

Before conducting a patrol, we sent a message to the people in the villages that a paramedic would be coming to treat the sick. Ah, when they heard that, they would come out of the forest, and we would use the opportunity to register them as residents. So, in that time, the district heads and the paramedics had to cooperate closely. This was very important for the remote areas. The Dutch doctors paid great attention to health services for the population. In every district there was a paramedic, and he had his own schedule for visiting the villages. When going to visit villages on the coast, the paramedic could use the boat of the district head.

\section{KAIN TIMUR}

The adat practices of the Ayamaru were more rigid. It was difficult to infiltrate their communities to change their ways of life, for example, with respect to kain timur (pieces of ceremonial, woven cloth originally from the Southeastern Moluccas).

Kain timur had a strong influence on every aspect of community life. Sons always had to help their parents, because the good name of the family could bring kain timur. They would not permit their sons to be sent to faraway schools. Nor were they allowed to become police officers or to serve as soldiers, or to attend the Jongens Vervolgschool (JVVS, follow-up school for boys). Daughters had to help their mothers. The parents cared for their daughters until the time came for them to marry. Kain timur was the highest, most valued form of property. It was used as bride wealth and as a means of paying fines to settle all kinds of adat cases. The adat leaders, who were called bobot, owned a lot of kain timur. When disputes occurred, they were the ones who determined how much kain timur should be paid and they were the ones who settled disputes. The bobot had enormous influence. They regulated war and peace with other bobot and other tribes. When one of them gave an order, everyone was willing to follow his order because, ultimately, he was the person responsible for all the consequences.

I once handled a murder case in Ayamaru. I departed with the police to go to the place where a murder had taken place. We left early in the morning, and arrived to find the corpse laying there. The man had been murdered. The night before, his wife had come to tell their children, and 
their children had reported it to me. We went to ascertain what had happened, we buried the murdered old man and then we returned. A few days later, we reported the event to the HPB.

It was an adat matter. They were suspicious of one another. People from another village probably suspected the old man of sending a suangi (evil ghost) to kill one of their people. Following their custom, they just surmised who the person was using mawi (magic). If the mawi indeed indicated the person who they suspected, yes, then they took action and killed the person. That was what they did to that old man, who was living with his wife in their garden. The murder began to precipitate a tribal war, but we prevented that because the police took swift action and succeeded in arresting the perpetrators. They perpetrators were caught and then processed. In this way, we found out the background and everything that led up to the murder, how many people were involved, and who was to be held responsible for the consequences. The perpetrators were arrested, processed and punished.

THE SEBYAR TRIBE

The Dutch government always carefully thought through considerations about whether or not it was appropriate to open a given district. For instance, the district of Arandai was not opened because it was surrounded by swamps. The inhabitants' houses were erected right on the swamps too. If you wanted to go anywhere you always had to go by boat. And if you wanted to meet with them, you had to use a boat. At the time the population of Arandai district totalled 5,000 people. There were a great many mosquitoes and gnats. Yet the people of the Sebyar tribe have managed to survive in this area until now. At that time, a doctor and a paramedic regularly came to help the ones who were sick.

Because it was not feasible to open this area, another area was opened instead, namely, Merdei, which at that time was the site of an oil drilling company. Before I was posted there, officials had probably already conducted a survey and seen that the area had certain potential. And when I went there, the district of Arandai was closed and Merdei opened. The population was not forced to move because they really could not move to another place.

When they were invited to move to a dry plateau, they were unwilling, because they had always lived on water. And sago trees grew by the 
river, so it was not hard for them to find food. So, for the time being, we could not force them to move. Only later, because the oil drilling companies were coming in and having an impact on them, were they willing to move. They were not forced to move to dry land since they did not know anything about gardening. They were happier to live on boats looking for fish in the sea and in the rivers.

The new district of Merdei was opened after the oil company, Nederlandsch Nieuw-Guinea Petroleum Maatschappij (NNGPM) conducted survey activities there. So the Arfak people were already quite familiar with the company's activities. They also worked as labourers to cut down trees, and so on. They rejoiced when the district post was opened, because by that time the NNGPM company had closed. They wondered, now that it had closed, what was next? It was their leaders who asked that the area be opened, so the government could establish a district there. And that is what happened. External communications would be managed by airplane from Merdei to Manokwari. For that, an airstrip had to be cleared. The work of clearing the airstrip was done using the labour of the community itself. They did not use tractors or other modern equipment. Who was going to bring a tractor up there? The people worked on it with their own hands. They used machetes, axes, hoes and shovels. There was a team that cut the grass, a team that felled trees, and a team that cut the buttresses of the trees. They worked voluntarily and were willing to be paid in contact articles. The Dutch government at the time used goods as contact articles. Since the people were not yet acquainted with money, we asked that they be paid in contact articles, and the government provided the supplies.

The people already grasped how important outside communications were for their area. They did not question the use of the land for the airfield. They permitted its use without asking for payment. At that time they had no idea yet about compensation for land. Today they must be given compensation for land.

ASSISTANT CLERK

My friends and I completed our education at the Opleidingsschool voor Inheemse Bestuursambtenaren (OSIBA, School for Indigenous Administrators) after three years of study and we graduated in 1954 . 
I was placed in Manokwari as a candidaat bestuurs assistant (assistant administrator candidate), and I was seconded to the office of the HPB of Manokwari. As it happened, I had worked in the Landschapsrechtbank (Regional Court) division as an assistant court clerk. I assisted my boss for a year.

Then I worked as a civil servant, in keeping with my education. After a time a number of us who worked under the HPB Manokwari were enlisted to assist the district head of Manokwari. And the main work we were assigned was to conduct patrols to the district areas and villages. We conducted patrols from the coast to the mountains and into the hinterlands. In Manokwari we got to know the Arfak people, who lived scattered from the coast all the way to the mountains.

Mount Arfak, which is now called Mount Umsini, is 2,000 to 3,000 metres high. So our task - being bestir muda, or young administrators, as people called us - was to make visits to the villages to collect data and see to the implementation of development projects and community development. Since at that time the Dutch did not provide funds in the way it is done today, the people took their own initiative to develop under the the guidance of the district head, or the HPB and other government workers, in the fields of agriculture, plantations, and so on. For example, with the Department of Agriculture and Plantations, what was funded was the implementation of the work in the field. So there were farmers who were paid to clear land, clean it up and plant it with crops. Or to replant it, as in Warmare, where there was a cocoa plantation at first, but then it was cleared and replaced by a palm oil plantation. That was the work of an administrator. Moreover, as young administrators, we had to practice how to work in the midst of the community. Above all, we had to get to know the community and their environment, their adat, and the practices of community life. Once we discovered things that, based on our considerations, should be developed in our endeavour to develop the community, these things had to be reported in writing to the HPB. Our data collection results would be given attention by the government in implementing development. Therefore, as prospective administrators, we undertook district head were forwarded to the HPB and the HPB forwarded them to the resident. 
FULL INITIATIVE WAS REQUIRED

That was the main job of an administrator. Additionally, we had to take the initiative regarding things that needed to be done in the government at district level. Perhaps people had to be brought down from the mountains, or scattered communities had to be gathered together to establish villages using their own resources. With the guidance of the district head and his employees, the people were taught how to build a village on their own, using local materials and without getting funding or other assistance from outside.

Thus, what is called 'autonomous development with little funding' was already being done in the Dutch period. When developing villages in the swampy areas with people who were still primitive, the houses that got built were quite simple. They were erected on platforms with roofs made of sago palm leaves, and walls made of sago palm fronds or bark. These houses looked good, too. Health workers provided information to the communities on how to maintain their health and build healthy homes.

So the work of the agencies seconded to the district head was coordinated. The district head did not organize it all by himself, but in conjunction with the Departments of Health, Agriculture, and others. And that is what happened in each development effort in the villages - which were known at the time as kampung rather than desa. Village development was not much different from one village to another. The community did it themselves without being forced to do so. We encouraged and provided them with understanding, so that they would build teachers' houses as well as their own houses. They also built school and church buildings by themselves.

It was not necessary to gather everyone together to hold a meeting beforehand, in order to determine how many houses had to be built, what kinds of building materials would be used, and what would be acceptable. No. It was enough for the district head to consult with the existing government agencies, especially with the Health Office and the teachers. The teachers were very important in the villages, because they lived there all the time and had to engage the participation of the community to ensure that education for the district head was very attentive to the teachers since they taught the schoolchildren. The health paramedics were also given attention, as were the police. At that time the police 
played their role in conjunction with the district head. When anything happened that endangered the community and called for security, the police were deployed to settle things. But they did not act as they pleased; rather, they had to act properly, without resorting to violence.

The Arfak people were famous for being difficult to rule. They did not pay much attention to orders from the government. And the police at the time could take action based on the existing regulations on policing. The district head ruled, and the civil government and police were his assistants. In cases where it was deemed necessary, the district head could act to enforce the law, as he had the authority to be a law enforcer. So the people at that time recognized the government as a means of law enforcement and public order. There was good cooperation between the Arfak tribe and the district head. The government ran well because we Papuans worked well, and what was done was accepted by the HPB, provided that no scandals arose, if the administrators imposed something on the community. Ah, that was prohibited by the HPB. As long as we were in tune with them, the people had no objections.

\section{COUNCIL SEGRETARY}

I once served as the secretary to the Streekraad (Regional Council) in Teminabuan. The Streekraden were governed by government regulation. They pre-dated the establishment of the Nieuw-Guinea Raad (New Guinea Council). There was Streekraad Anim Ha in Merauke, Streekraad Dafonsoro in Hollandia (Jayapura), and in the place where I served, Streekraad Maybrat, on which I served as secretary. It was a democratic system.

Among council members there was a mutual exchange of ideas and knowledge among people who had long been involved in government. Meaning that the council usually kept pace with or took part in developments in the government, so the work was not too difficult, because the people involved - village heads, tribal leaders, community leaders - already had a general knowledge of things. They understood how the government worked. They automatically knew what was happening. And they were guided by the HPB and other government leaders. They understood the tasks of the Streekraad, since the Streekraad regulated what went on around the community itself with regard to people's rights, 
in keeping with their adat rules. The chairman of the council at the time was HPB E.A. Polansky. He was later replaced by HPB Alex Onim.

We can compare the government system in the Dutch period with the current government system as follows. Currently, we have to wait for provisions to be outlined, for example, by the provincial centre (Jayapura), before they can be implemented in the field. In the past it was not like that. We were free to develop initiatives based on what was there. When it came to matters in which the government had to intervene, only then would the provincial government intervene--for example, if there was a disaster or catastrophe. Ah, it was then that the government intervened and helped out with the expenses incurred, for example, to clear the way to, and organize communications with the disaster zone.

But as long as the community could work on something on their own, the government did not intervene, since it took place at the initiative of the people themselves. When the government wanted work to be done on something, the government provided funds to cover wages for the people who did the work. That is the difference between the Dutch period and the present period. Today, the people do not take the initiative, but wait for instructions from the government, perhaps because this facilitates communications. But if the people themselves take the initiative, yes, let them. And that was what happened in the Dutch period.

Why did this happen? Perhaps it was like this, in my opinion, in the time before anyone talked about independence. Perhaps the Dutch saw that the people had the capacity and the interest, so they encouraged them to work on their own. You can see how this differs from the situation today, when people are not forced, but pressured to work, although they have no desire to work. Now people are used to working because they are paid and because various facilities exist. After the transfer of Papua to the Republic of Indonesia, people shouted: 'Give us money first, then we'll work!' So it is far different. How come that the attitude of people has changed so dramatically? Maybe because of the influence of other people and the limited opportunities available.

Nowadays, money is given more priority than the public interest. So development is seen as some kind of object. According to the people here, the people from outside Papua who came here changed the democratic ways of thinking of the Papuans. It was the people who came here from all over the place, who changed the good habits that existed here. Maybe they think we are lazy if we do not have a job. But Papuan people 
today do not think like that. Now they are demanding better access to the labour market, more loudly and more forcefully than ever.

After the end of 1978, I was demoted from being a KPS to become a camat. Whether it was a step down for me - I myself could not tell the difference. A KPS, meaning kepala pemerintahan setempat (head of local government), supervised five to eight district heads. A camat (sub district head) only headed one small area. The status of a camat was lower than that of a district head. His rank was a little higher than that of a lurah (municipal ward head). And the status of a lurah was higher than that of a village head. But a person who served as a village head was a community leader, whereas one who served as a lurah was an active government employee. The village head was autonomous, but the lurah was not. In any case, the camat was the head of one or two kelurahan (municipal wards) and a few villages.

\section{THE ADMINISTRATION UNDER UNTEA}

During the UNTEA period, the Dutch administrative system still held sway. The employees of the Trikora (People's Triple Command) brought into this area by Indonesia were still acclimatizing. After that, the exDutch employees were directly replaced by shifting them out of their positions. Whatever was brought in from Indonesia, that was what was put into operation here. Former government employees like us had to go through upgrading, training, and courses. When we left, our job vacancies were filled by other people. And when we returned after following all the programmes, it turned out that there were no places left for us. All the vacancies had been filled by newcomers. So we had to wait for another vacancy or were transferred to other areas. Many people appeared to be out of work at that time. And in fact not only back then, but still up to now. Thus, I can say that the government of this republic appears to accommodate many unemployed people who are provided with food. Whether a government employee works or just sits and walks around, he is given an allowance for food. The employee's function is no longer appropriate to the field he pursued as a civil servant.

The UNTEA period ended in April 1963 and the Act of Free Choice was held in 1969 based on the New York Agreement of 15 August 1962. The Indonesians had a greater role in the Act of Free Choice. Sudjarwo Tjondronegoro was most active in propagandizing the Act of 
Free Choice until it was carried out. If I am not mistaken, the initiative to carry out the Act of Free Choice according to a representative system and not a 'one man one vote' election originated from him. It was also influenced by pro-Indonesia Papuan figures at the time as well. They used the momentum to choose a system that applied here according to adat practices. When tribal chiefs and adat leaders speak, people will follow them without a comment. So at that time in Manokwari there was a number of community leaders involved, such as paitua Kawab, who was also the bupati at the time.

They were regarded as community leaders and adat leaders. The community leaders knew the adat and traits of Papuans. Generally, Papuans from across the country were nearly the same. When someone was looked up to as an important figure, everyone regarded him as a leader, and took whatever he said to be true. Each tribe had its own leaders. If a leader from the interior spoke, the people of the interior listened to him. The same was true of adat and community leaders from Biak-Numfor, Wandamen, or Serui. So at the time, this system was used in the Dewan Perwakilan Rakyat Daerah Gotong Royong (DPRD-GR, Regional Council of People's Representatives Mutual Assistance), which was not composed based on general elections like the Nieuw-Guinea Raad.

The Nieuw-Guinea Raad ceased to exist as of 1 May 1963. But if you read the New York Agreement, the rights of citizens were guaranteed and were supposed to have been respected and maintained by the government of the Republic of Indonesia. The people should have been granted their rights to engage in politics in a democratic manner. But they committed action against and arrested anyone who spoke about such rights. Yes, that kind of thing actually happened! What is more, at the time, the Free Papua Movement (OPM) was spreading. Ah, the name OPM was not to be mentioned carelessly. If someone used the name OPM, the person was branded as a subversive or killed. In any case, the plans for the Act of Free Choice were really made by them and sponsored by Soedjarwo Tjondronegoro.

We civil servants could not do a thing, because we had to carry out whatever the government had decided. So all the plans were arranged here and then firmed up in Jakarta for implementation. Because the Act of Free Choice had to be implemented successfully here, it was implemented using violence. If they had not used violence, they might not 
have won. The government did not recognize compromise and did not ask for public opinions. The government stipulated there was only one option: We had to integrate with Indonesia! There was no other possible response.

The people who sat on the Dewan Musyawarah Pepera (DMP, Consultative Council for the Act of Free Choice) were picked from the villages. They were not elected. The camat would ask the person if he could speak. Our impression was that a dialogue would be held in the DMP. So the ones appointed were elders and leaders who were articulate speakers. They were brought to Manokwari and accommodated by the Navy. They were quarantined for over a week leading up to the Act of Free Choice Assembly in 1969. During the quarantine, the people who would be speaking in the Assembly were designated by the Indonesian government. They were secretly taken to receive indoctrination. They received instructions about what they had to say.

\section{WHATEVER WE DID WOULD BE WRONG}

While they were in quarantine, none of them knew what any of the others would be talking about. They were afraid to approach one another because they were surrounded by Indonesian soldiers. Later, when it was time for them to begin conveying their stances, one by one, each of the 20 who had been decided upon stood up to speak. The people speaking had no idea what the other speakers would say. They only knew that all those who had already spoken had invariably chosen in favour of joining Indonesia for whatever reasons.

Yes, that was it: Just agree. And all of them agreed. If you did not agree, you might be briefly tortured and put to death! If we look at the situation in Manokwari at the time, since everyone got away by speaking with one tongue (choosing to join Indonesia), nothing would happen, meaning that they had given their votes according to the will of the Indonesians, so nothing would happen to them. But the voices outside remained strongly opposed, to the point that people were taken to Arfai (the former Papoea Vrijwilligers Korps complex, then a prison).

So those of us who sat in the Act of Free Choice Assembly began to wonder whether or not what we had said would save many people. That was the thought that crossed our minds. I asked: 'Will the people and I survive or not?' As for the others, all they could do was to wait. Yes, 
if somebody spoke the wrong words, all of us would be killed! So would the things we said save ourselves as well as other people, and the people who might be ready to be shot, and our communities? That was the one thought that haunted us.

We, as local government heads, or KPS, had to stand beside our communities, because they lived in our areas. It was hard for us on the side of the government to change people's minds because they never wanted to compromise. The bupati could do nothing either. He only gave a warning: 'Remember not to sacrifice the people.' When he spoke like that, we knew what he meant. We had to see to it that the people would not speak about Papuan independence, about the plebiscite, and so on.

And the Indonesian government emphasized that the plebiscite had been replaced by the Act of Free Choice, and that the two were just the same. How were we supposed to explain that to the people? If we spoke it would mean we would be seen as provocateurs, and so on. It was difficult for a government administrator. We were forced to prevent the community from speaking up (against Indonesia), so that we could save many people. Because if we spoke up, then we and the people would be killed. That was clear. Mr. Ortiz Sanz (the UN representative) could do nothing because he was just one person. He spoke in English, and we did not know whether or not the translation provided was accurate. Everything had been prearranged, like the time when Ortiz would speak. We had taken account of all the dangers. Did we want to jump into the fire or protect ourselves from the fire? We just backed away, because the indoctrination was already in progress. The Indonesian government came in and ruled Papua accordingly. However, if at that time, things had been regulated the way they are today, where it would be necessary to hold a dialogue with the Council, then it might all have worked out according to our wishes as Papuans.

The members of the Consultative Council for the Act of Free Choice were determined to choose freely, but could not act on that desire. Before we entered, we remembered that we had to save ourselves and many other people because a battalion of troops of the army of the Republic of Indonesia had already landed by freight ship and were surrounding the entire city. So who would dare oppose them? 
After the end of the Act of Free Choice, movements emerged, including the OPM. Those movements closed us off from further opportunities. Those of us who had statuses and positions in the government no longer had the trust of the people. They said: 'Ah, these people and these officials are all talk and no action.' In the end, the true functions of government were not being performed well. If we demanded anything from the government of Indonesia, we would be seen as rebels. And if we demanded a lot, we would be ignored. In our view, they (the Indonesian government) made use of the OPM as a pretext for dredging away more riches. They set up the situation to make it look as if something had happened, so they could stage all sorts of police and military operations. That way they could make money. Seeing this, we administrators could do nothing. We were just spectators. What was true from our perspective was considered false. We were regarded as subversive and opposed to integration.

In 1962, big companies and investors began coming into Papua. Their people came in and filled the land. What were we going to do about it? As government people, we had to implement government programmes, so that they could carry out all their plans in this land. It was hard in every way, and whatever we did, we were wrong! If we did not act, we were wrong; if we acted, we were also wrong. So we had to look at which position was better. If we had no friends, right, it was best not to try anything! We were also worried because we were former Dutch government employees. If we were even a tiny bit guilty, we would be seen as ringleaders.

At the time we assumed that the implementation of the Act of Free Choice did not clash with the official decision of the UN. We wondered how it was that it could be altered the way it had been without going through proper legal procedures. But who could we discuss this with? The one who organized and implemented the Act of Free Choice was the Indonesian government itself. The other parties who co-signed the New York Agreement never showed up to say: 'Don't!' No one acted to provide supervision. 